\title{
Chief Zebrudaya as an Archetype of Molièresque Persona: A Satire of Nigerian Postcoloniality
}

\author{
Dr. Richard Oko Ajah \\ Department of Foreign Languages, University of Uyo, Nigeria \\ Email: ajrichard2000@yahoo.com
}

\section{Doi:10.5901/mjss.2014.v5n9p599}

\begin{abstract}
The Nigerian comedy series, "The New Masquerade" or "Masquerade", remains "one of the Nigeria's longest running and most watched television show as transmitted by Nigerian Television Authority in the 80s and 90s. The episodic representations, although full of caricatures and farcical qualities, express serious disillusionment, becoming an indictment of the postcolonial Nigeria. The sense and science of humor in The New Masquerade are informed by its postcolonial linguistic appropriation. The language of the soap is full of heterolinguistic permutations, modifications, transfigurations and total transgressions of conventional English structures, recreated and manipulated with local parlances and dialects as raw material for the service of the viewing masses. The character of Chief Zebrudaya is typically encapsulated in the persona of the classical French dramaturge/playwright, Molière. This study is comparative. It shows in what ways Nigerian Zebrudaya shares some artistic and socio-cultural features with the French Molière or his characters, despite their spatial, temporal and artistic differentiations. The paper also evaluates thematic and structural relationships of Zebrudaya and Molière. It goes further to demonstrate how the Nigerian comic character dismantles European language to enable him 'write back' to the Center. This paper strongly affirms that Zebrudayan English is not a sign of 'destruction' of Standard English as critics purport but a deconstruction that produces a postcolonial linguistic particularity that oscillates between Standard English, Nigerian Pidgin and Ibo dialect.
\end{abstract}

Keywords: Satire, Chief Zebrudaya, Moliere, New Masquerade, Nigerian Postcoloniality

\section{Introduction}

Like all sectors of the public life in colonial Nigeria, cinema was controlled by colonial masters who censored cultures of representation. However, it is private merchants that brought cinema to Lagos as early as 1903; in August that year, the first screenings took place (Zajc, 2009, p.69). Before the advent of Kenneth Nnebue's film, Living in Bondage that Zajc considers one of the first blockbusters in Nigerian video film industry (p.69) and marks Nigeria's eponymous Nollywood and Nigerian video films in the 90s, Nigerian Celluloid film production was in vogue as the handiwork of artists from the Yoruba travelling theatre tradition (Hayes and Okome, 1997, p.21). Nigerian viewing public had relied on exotic films, soaps and series shown in the public TV stations. However, the Nigerian mass media comedy, "The New Masquerade", remains "one of the Nigeria's longest running and most widely accepted television show, transmitted by Nigerian Television Authority in the 80s and 90s, that impressed the Nigerian TVspace. Chika Okpala played the role of the protagonist, Chief Zebrudaya who, as one of the major characters in the soap, ended up acquiring mythical elements to become a cultural personality in Nigerian social landscape. The episodic representations, although full of caricatures and farcical qualities, express serious disillusionment, becoming an indictment of the postcolonial Nigeria. The sense and science of humor in The New Masquerade are informed by its postcolonial linguistic appropriation. The language of the soap is full of heterolinguistic permutations, modifications, transfigurations and total transgressions of conventional English structures, recreated and manipulated with local parlances and dialects as raw material for the service of the viewing masses. The character of Chief Zebrudaya is typically encapsulated in the persona of the classical French dramaturge/playwright, Moliere. This study is comparative as it considers Molièresque works and the New Masquerade as a comedy that "makes its efforts known by discussing grave issues of social and domestic concerns lightly" (Okome, 2007, p.162). It shows in what ways Nigerian Zebrudaya shares some artistic and socio-cultural features with the French Molière, despite their spatial, temporal and artistic differentiations. The paper also evaluates thematic and structural relationships of Zebrudaya and Molière. It goes further to demonstrate how the Nigerian comic character deconstructs European language to enable him 'write back' to the Center.

The search for a paradigmatic relationship between the classical French playwright and actor and contemporary Nigerian comic actor is not literarily anachronistic because of what Bailey (1998) calls conditional universalism of the 
principle and practice of artistic purpose and usefulness and some universal quality of Molière's plays, which have been adopted, translated and staged by students and scholars of theatre in different countries of the world. In her doctoral work, titled "Fielding and Molière", Nelson (1971) shows how Molière, placed among the group of great masters of the comic mode, influenced the seventeenth century English writer, Henry Fielding who adopted Molière's The Miser and The Mock-Doctor. Such adaptations are now modernized version of classical text, given new settings as shown in Cristina Skinner's "The Misanthrope: Accepting the Notions of Molière into a Modern Society" which demonstrates the conceptualization, rehearsal process and critique of the direction of The Misanthrope, produced during the fall semester of 2010 for Jonny Carson School of Theatre and Film. Aside the influence of Molière on early francophone African drama such as Guillaume Oyono-Mbia's Trois Prétendants...un mari, adaptation of his plays remained early tradition of African scholars and dramaturges which made the Ghanaian Efua Sutherland to advocate appreciation not recreation of Molière in African theatre in her search for artistic authenticity (Bailey, 1998, p.15). Unfortunately, the influence of Molière has not waned in Africa. The South African Mama African Theatre Company has recently produced A Molière in Soweto, which is as well an adaptation of Molière's Le Mariage forcé, a drama directed by two French directors.

In Nigeria for example, the playwright and critic, Dapo Adelugba's That Scoundrel Suberu is an adaptation of Moliere's Le Fourberies scapin; its stage presentation manifested the theatric ingenuity of Femi Osofisan, who belongs to second generation of Nigerian playwrights and dramatists and whose acting in Adelugba's play would have been facilitated by his exposure to French classical literature before and during his scholarly sojourn in France. Back to Masquerade, although Chief Zebrudaya might not have been exposed to classical writings of French origin as to imbibe the technique and technicality of Molière's comedy, his comedic wits and concept of humor find parentage in Molière's neoclassical theatre. In essence, the term "paradigmatic relationship" forecloses scholarly influences but foregrounds artistic ingenuity of Zebrudaya and Molière, though separated by 300 years; both dramatic personas have become cultural personalities in Nigeria and France respectively through their exploits in "committed" comedies. While studies on Molière's works are widespread, Zebrudaya's comedy has not been given much attention by scholars. Studies on the theatrical experience of Zebrudaya have been rather centered on the linguistic and not on the literary or thematic which is this paper's preoccupation. Teilanyo (2010) has shown the linguistic phenomenon of Zebrudayan English, a particularity that sits between Nigerian Pidgin, Standard English and Igbo dialect; others such as Ilagha associate the falling standard of education in Nigeria with what he calls Zebrudaism which "does violence to English grammar" (p.55). Although this paper acknowledges such works, but it goes further to refute some generalized scholarly judgments on Zebrudaya's linguistic phenomenon which is purely postcolonial as it will be shown later in this study. The verbal censorship from this "Nigerian academia" on Zebrudaya and his comedic English is tantamount to Molière's notorious Querelle with seventeenth-century Academie Française or Les honnêtes hommes that queried his ab/use of classical rules of theatre.

\section{Molière: Classical French Comedy and Society}

Pierre Corneille, Jean Racine and Jean-Baptiste Poquelin, popularly known as Molière, are the troika of French classical theatre which was polarized into tragedy and comedy, though Molière's fame cuts across cultures, spaces and time and his works have retained a more universal appeal than those of his contemporaries. He not only created the most popular comedies of the day, but also revolutionized the comedic genre in seventeenth-century France (Mason-Dean, 2009, p.7). Born in 1622 in France and lived for 51 years like Shakespeare, Molière was a dramatist, performer and director, leaving almost about three dozens of plays to his credit and provoking outcry in French literary and religious circles, majorly owing to his L'Ecole des femmes (1662) and Tartuffe (1664). His other plays include L'Avare (1668), Le Médecin malgré lui (1666), Le Malade imaginaire (1673) to mention a few. Pierre Zoberman (2005) declares that Molière's domestic organization of his plays revolves around questions of power and knowledge, or more accurately that the domestic interior is the stage of an intense power struggle since the $17^{\text {th }}$ century is noted for being a period of extravagance and power for the French monarchy of Louis XIV, also known as The Sun King who maintained the French social order categorized into First, Second and Third Estates. Since the French social order dictated in large part how people interacted, and worked ideally when each order cooperated with the others (Mason-Dean, 2009, p.11), Molière, therefore, assumed self-imposed responsibility of social commentator and critic, through his comedy of character and ideas, of French Fealty, using it as the basis of conflicts in his plays (p.14).

In L'Avare, a conflict exists between Harpagon, a wealthy widower and his two children, Cléante and Elise. It is his miserly life and conflicting desires that introduce this domestic quarrel and condition his relationship with his progeny and his servants. His children are in a dilemma because Harpogon is in love with Mariane, a beautiful but poor young girl that Cléante wishes to marry and Elise who is in love with Valère, Harpagon's servant, must marry a rich old man who can take her without a dowry. Though he has a box of gold buried in his garden which is eventually stolen, his son Cléante 
intends to borrow money despite stringent rules and high interest, charged by avaricious money lenders. Domestic conflict of interest establishes this dysfunctionality of Harpagon's family; however Cléante and Elise eventually triumph over their father, showing the victory of the new generation over the old in the play's denouement. Such plots are later exploited in francophone African theatre; Guy Menga's L'Oracle depicts Louaka's triumph over her father Biyoki in a struggle involving her schooling, marriage and bride price (Edem, 2000, p.268), and Oyono-Mbia's Trois Prétendants...un mari (1977) shows how Juliette is being prevented from marrying Mbia, but being 'sold' to the highest bidder, a rich old man. Following the Molièresque tradition of Commedia dell'arte, inherited from Italian comedic actors, L'Avare satirizes French classical society's eccentricity, inhumanity and materialism while Tartuffe and Le Misanthrope are mockeries of seventeenth-century religious and social hypocrisy. Tartuffe, named after its pro/an/tagonist, presents Tartuffe whose maneuverings secure him a place in Orgon's and Mme. Pernelle's heart and home. Despite premonitions of his son, Damis, Orgon decides to force his daughter, Mariane into marrying Tartuffe who will incidentally inherit his benefactor's estate. It is only Orgon's wife, Elmire whose efforts help in unmasking the impostor and hypocrite, Tartuffe who is made to face the wrath of the law. In Le Misanthrope, hypocrisy is maximally satirized in the character of Alceste; for Skinner believes that Alceste represents the changing social behaviors of the century and the constant battle that modern society now holds with fads, trends, and celebrity status, and also signifies the need to maintain old order, morals and codes that distinguish nobility from the lesser middle class citizens. This aristocratic Alceste "judges all actions by absolute standard of virtue, and he judges others not to reform them, but to denounce them and free from them: in this lies his misanthropy" (Epstein, 2001, p.98). Inherent in this theatre for social responsibility is Molièresque didacticism that ensures the victory of good over evil in his plays, yet Tartuffe remains a social indictment of seventeenth-century French religion polarized into two doctrinal groups of Jesuits and Jansenists, into the dominant and the dominated, and into the persecutor and the persecuted. If Tartuffe presents the comedian's missiological discourse, other plays criticize knowledge and medicine.

Zukaitis (2009) believes that Molière's L'Ecole des femmes, juxtaposing sexuality and spirituality, gave rise to a literary feud that lasted for over a year and generated multiple parodies, critiques, and counter-critiques. The playwright/actor uses the play to address as well the question of knowledge of Christian theology and omnipotent classical aesthetics, employed to condition womanhood and writing in the seventeenth-century French society. Both theological and textual authorities are subversively challenged through comical and satirical theatricalization. Le Médecin malgré lui and Le Malade imaginaire represent Molière's satires of seventeenth-century medicine and its purported scientism. The medicine Molière knew throughout his life, says Hall (1977) was more authoritarian than empirical; that it could be formalistic even ritualistic, to the detriment to the patient's health; and its orientation was rhetorical rather than clinical; such are attitudes to which Molière's satire points accurately time and again.

Stratification of seventeenth-century French society, filled with social tensions and conflicts, formed raw materials for building Molière's texts. His alignment with the downtrodden that inhabit the Third Estate of French social order but venerated in his plays pitches him against the professional and the ecclesiastical who perpetuate the culture of social centrality and marginality and are satirized in L'Avare, Tartuffe, Le Bourgeois gentilhomme, Le Malade imaginaire, L'Ecole des femmes and his other numerous plays. His critical views of the Church, especially in Tartuffe and L'Ecole des femmes, would have denied him Christian burial at death but for the prompt intervention of the Sun King. Before, during and after Molière, social realism has been part of tragic and comic theatre because the French classical playwright does not only share some similarities with The New Masquerade's Chief Zebrudaya, but also with the "Ogbuefi and Ashiwaju" of Nigerian theatrical school, Wole Soyinka who "demonstrates his revolutionary ideal through the comical and satirical aesthetics of his plays" (Musa, 2006, p.225). In his thesis of universal artistic ancestry, Musa highlights common areas of difference in these words:

what distinguishes one playwright from the other is the nexus of environment and the sheer artistic ingenuity, creative experience, educational background, literary or artistic orientation and aesthetic attachment among others of one playwright to the other (Musa, 2006, p.219).

Although Chief Chika Okpala as comic scriptwriter and comedic actor does not perfectly fit in Musa's paradigms, except in natural artistic ingenuity, Soyinka does by virtue of his unparalleled artistic training in language and literature in Ibadan and Leeds. Influenced by the Italian Commedia dell'arte like Molière, Soyinka's The Trial of Brother Jero, Jero's Metamorphosis and other plays present a complete satire and mockery of Christian religion in Nigeria. Like Molière's Tartuffe, Soyinka depicts "Pastor Jeroboam as the ungodly man of God transiting from poverty to affluence through deceit, hypocrisy and the natural endowment of tongue of fire" (Musa, 2006, p.221) in his attempt to textually replicate Nigerian social and spiritual atmosphere, charged with the commercialization of churches in Nigerian towns and cities. 


\section{Chief Zebrudaya: Television Comedy and the Postcolonial Nigeria}

Icheoku and Masquerade are two Nigerian television series that Diri Teilanyo identifies as earliest mass media comedies (Teilanyo, 2008/9, p.73). The Nigerian Television Authority produced most of these TV series, including the serialization of Chinue Achebe's Things Fall Apart, directed by David Orere in 1987 which, as claims Zajc (2009), increased the popularity of televised theatre plays. Although the TV series of Things Fall Apart created impact in the minds of both literate and illiterate multiethnic viewing public especially with its tragic plot of the death of Ikemefula, Masquerade or The New Masquerade, as it was later called, like Molière's classic comedies, remains the most celebrated indigenous televised comedy in Nigeria and Nigeria's longest running and most watched TV show, created by the ace comedian James Iroha.

On his return from the United Kingdom in 1967, James Iroha created Masquerade, a TV comedy series that metamorphosed from a fifteen-minute radio program, In the Lighter Mood by Bob Nwangoro and produced by Nigerian Television Authority, Enugu and Lagos. Iroha confirms that the comedy's texture is representational of his family, gifted in comedic antics; his father is transformed to Chief Zebrudaya (or ZB for short) and his mother, Ovuleria, while other characters such as Jegede and his wives Akpeno and Ramata, Nati, and Okoro Maduekwe constitute a crop of his father's friends, according to Mbamara and Nnorom (2006). James Iroha, himself, played the role of Chief Zebrudaya's houseboy Gringory, together with Clarus (David Ofor), especially to parody his father's Akwa Ibom-born servant Etudo who took care of himself (Iroha) and his sister. On The New Masquerade's copyright, controversies surround the patent of this TV comedy and which eventually caused its untimely "death" in the 90s, especially between NTA, James Iroha and Chika Okpala (Chief Zebrudaya) which Iroha's interview alluded to, though Teilanyo (2010) explains that all the texts are named. The LPs and audiocassettes are produced under two troupe names; to which their authorship is ascribed, namely, James Iroha and the Masquerade and Zebrudaya and His Concert Party. As a TV series, all episodes are titled such as "Governor for Sale", "Senior Sinner", "Stop the Wedding", "Unholy Baptism", "The Visit of Mr. Bewitch Bankrovitch", "Woman Contractor" and others which are recorded on audiocassettes, audiovisuals and VHS.

Like Moliere's plot that reflected the seventeenth-century French classical family for example in L'Avare where Harpagon lives with his two children and servants, the comedy The New Masquerade parodies a typical Nigerian family that has attended some 'enlightenment' since Chief Zebrudaya is a returnee and veteran of World War 2. Chief Zebrudaya's family is made of himself, his wife Ovuleria, his daughter Philo, and two male grown up servants, Clarus and Gringory who has intertribal origin (of Ikot Ekpene and Arondizuogu). The setting is mainly the sitting room of Zebrudaya's home, though scenes of other places such as Jegede's home are interludes that spice up the protagonist's house of laughter where all occupants especially Clarus, Gringory and Zebrudaya are merchants of humor. The adult servants are clothed in short knickers so locally called, derogatory costumes that symbolize their positionality in the family hierarchy; they are receivers of Zebrudaya's multiple commands and Ovuleria's unending whims and ranting. As opposed to Clarus's and Gringory's customized short knickers and jumpa, Zebrudaya and his friend and rival Jegede Shokoya are always dressed in Nigerian agbada which is perceived as an emblem of bourgeoisie and aristocracy in Nigerian cultural landscape of post Civil War. The New Masquerade's themes were driven from Nigerian postcolonial condition, thereby expressing socioeconomic disillusionment of post-independence Nigeria.

The New Masquerade, like many literary works from the late 60s that engaged in "self-criticism and postindependence disillusion" (Griffiths, 1999, p.143) or did critical evaluation of African "suns of independence" such as Kourouma's Les Soleils des indépendances (1968), Achebe's A Man of the People (1966), Armah's The Beautiful Ones Are Not Yet Born (1968), Ngugi's Petal of Blood (1977), Sembene Ousmane's Xala (1973), Alioum Fantouré's Le Cercle des tropiques (1972), Beti's Remember Reuben (1974) and others, engages in satires of Nigerian postcolonial experience that has been greeted with political and economic instability since Independence. Soldiers have joined politicians in "a reign of locusts" (Joe Ushie) that has enthroned the culture of corruption and brought untold economic woes to hapless citizens; the TV comedy does not spare the neocolonial tendencies of the West as that is what the title "The Visit of Mr Bewitch Bankrovitch" intends to achieve.

In "The Visit of Mr Bewitch Bankrovitch", Chief Zebrudaya is approached for a business deal by this white man that "speaks through the nose" who is a Russian Medical research fellow for the sale and marketing of canned beers and his company's representative in Africa. He informs Chief Zebrudaya of the profitability of garbage, scraps of cars and old tires that adorn streets of Nigerian cities and therefore draws up the deeds of their partnership. The play shows that Mr. Bankrovitch ends up pricing Nigerian cockroaches and rats N1.30 and N7 respectively, thereby ridiculing Western capitalism and mercantilism that appears unending in Africa. In "Stop the Wedding 1 \& 2", Ovuleria is worried of Chief Zebrudaya's sickness. Called by Chief, Dr Sanni Audu informs him that he is suffering from high blood pressure, due to excessive drinking. The second part depicts the secret planning of Philo and Gringory who intend to get married without 
the knowledge of Chief Zebrudaya, Gringory's master. And in "The Teeth of a Goat", the drama opens with Gringory's domestic chores. It is about Chief Zebrudaya's family squabbles and his mistreatment of Ovuleria, his wife. Gringory discovers a set of teeth while sweeping and believes that they belong to his master who uses artificial teeth. The probe into the ownership of the teeth unveils Chief Zebrudaya's battery of his wife who, being sick, eats 3 heads of goat four times every week, a prescription given by her personal physician. Through comedy, The New Masquerade, like Molière's classical theatre, engages in social indictment of Nigerian postcoloniality.

\section{Molière and Chief Zebrudaya: Humor and Social Commitment}

Molière's comedic oeuvre serves as an eye opener into classical French society and its defining factors because Molièresque comedy is socially committed. Through his characters such as Harpagon, Tartuffe, Alceste and others, the social dynamics of French seventeenth century is understood. Such literary preoccupations still characterize the (post)modern age as reflect themes of Nigerian TV series The New Masquerade, critiquing Nigerian postcolonial society. In Molière's L'Avare, Harpagon's poor servant Valère is in love with Elise, his master's daughter; it is an impossible love because this love only exists in the realm of expressivity, being unconsummated and impractical due to Harpagon's intriguing decision to marry her off without bride price to an old rich man and Valère's social status of Third Estate. The New Masquerade's Gringory shares some features with Molière's Valère in L'Avare. In "Stop the Wedding 1 \& 2", Chief Zebrudaya's servant, Gringory falls in love with his master's eighteen-year old daughter, Philomena. Anticipating a desperate antagonism, the love and wedding plan are shredded in secrecy until the discovery of Chief Zebrudaya's friend Prince Jegede Shokoya who laughs at such a marriage between a poor servant and his master's daughter and exposes it to Chief Zebrudaya and his wife, Ovuleria. "Stop the Wedding" as the play is titled, looks at the impossibility of love between two opposing social classes; Gringory represents Nigerian "Third Estate" while Chief Zebrudaya symbolizes the Nigerian society's "Second Estate". L'amour impossible that Molière's comedy presents in L'Avare, Le Médecin malgré lui and other works plays out in Nigerian postcolonial society, although, unlike Molière that resolves the conflict in the play's denouement, The New Masquerade presents the fleeing of the "illegal couple" that Gringory and Philo represent in the episode. Although "Stop the Wedding" parodies a typical family conflict, this Nigerian TV comedy also mocks at Nigerian postcolonial society and its social stratification that opposes the expressivity of "socially unbalanced" love. Like Valère and Elise in Molière's L'Avare, Philo's and Gringory's love does not matter, what matters is their asymmetrical social background and societal perception of such a relationship between a poor servant and the daughter of his master. This explains Prince Jegede's, Chief Zebrudaya's and Ovuleria's disapproval of the "controversial marriage", even though a pastor has accepted to join both of them in holy wedlock.

In "The Visit of Mr. Bewitch Bankrovitch", James Iroha and The Masquerades presents the manifestation of neocapitalist tendencies of the West, symbolized by a Russian businessman in Africa and his business proposal to Chief Zebrudaya. His name "Bewitch Bankrovitch" appears to be an anagram of "be a witch" "to bewitch", "bank robbery" and "bitch", an insight into the mission of the European in the postcolonial Nigeria. Although Zebrudaya denounces Mr. Bankrovitch's racial derogatory remarks on Africa and accepts his business proposal, the play intends to aver that neocolonial exploitation of African economy cannot be without indigenous collaboration. Mr Bankrovitch is an allegory of neocolonialism and its conspiratorial materialistic tendencies that continue to exploit developing nations of the world, including Nigeria. His desperation is revealed because he agrees to pay N1.30 and N7 for cockroaches and rats, two major animals that find their habitation in debris. Although cockroaches and rats are never for sale in Nigeria, the play represents the Europeans as materialistically desperate who, having transferred African commonwealth to Europe through colonialism, are now ready to take over its waste management and purchase the "unpurchasables". However, it is through the Russian businessman's exposition that we understand the modern management and transformation of wastes, so "The Visit of Mr. Bewitch Bankrovitch" appears to be as well an indictment on the Nigerian government and its society which allows indiscriminate dumping of refuse on its streets and roads. The play ends with the signing of the contract agreement and the advanced payment in Mr. Bankrovitch's hotel room where Chief Zebrudaya's order of indigenous tumbo liquor (palm wine), ugba and okporoko could not be taken because the Nigerian hotel only sells foreign gins, brandy, whiskey, rum and other western delicacies.

Chief Zebrudaya mocks at the westernization of Nigerian social life and the preference given to foreign goods over locally made products. He wonders why Mr. Bankrovitch cannot eat a common kola nut with ose oji without screaming for water, thus reprimanding him for his refusal to adhere to what Chief Zebrudaya calls "customary mannerism". Though it is cultural to administer kola nut and ose oji to visitors among the Ibos, Chief Zebrudaya intends to indigenize and dewesternize Mr. Bankrovitch who finds himself in Africa, thereby underlying the need for unprejudiced transculturalism. Chief admits to have adhered to western cultures during the Burma War by eating "carrot and Quaker oats without water" 
as part of victuals, thus justifying his refusal to drink brandy and whiskey in his homeland and his aversion towards exoticism, though he does not discourage Ovuleria, his wife from mixing her English with French parlance of "Qu'est-ce que c'est?" in his home. It should be understood that Chief Zebrudaya does not frown at transculturation but mocks at the conscious abandonment of indigenous cultures, just like Molière mocks at medical jargons and unhelpful Latin of French physicians of $17^{\text {th }}$ century who adopted rigorous exotic medical procedures in his comedies.

In Le Médecin malgré lui, the French dramaturge does not intend to demonize medicine in his plays, but its praxis and practitioners, shredded in esotericism. This explains why Béralde, in conversation with Argan, talks about those fit enough to survive treatment as well as their illness (Acte 3, Scene 5). Both methodology and medicine conspire to disillusion doctor's patients of Molière's age. Appraisal of Molière's plays shows the multifaceted layers of his social criticism, thereby agreeing that his "mockery of jargon is not limited to doctors, lawyers, notaries, scholars, précieuses and femmes savantes, hypocrites, now mocked for the abuse of jargon and other forms of rhetoric that seek to blind with science" (Hall, 1977, p.426). Like Le Médecin malgré lui and Le Malade imaginaire, The New Masquerade's "The Teeth of a Goat" remains a mockery of Nigerian medical system, though the play opens with revelatory elements of domestic quarrels and violence in Chief Zebrudaya's home. Unlike L'Avare where domestic disagreement which constitutes the pillar of the comedy's superstructure is between a father and his children, "The Teeth of a Goat" unveils Chief Zebrudaya's mistreatment of his wife, Ovuleria. Gringory's domestic chores enable him to discover a set of teeth in the kitchen, suspected to be those of a goat or Ovuleria's because ZB as she fondly calls him, habitually beats her at any slightest provocation and Gringory's diary keeps record of this abusive act of wife battery. Chief traditionally sees Ovuleria as an object that he bought in the Nigerian city of Port Harcourt or what he calls "a personal and bona fide property", therefore she can be used and abused without interference of anybody. The play implicitly frowns at the patriarchal objectification of woman in Nigerian society, a traditional practice that perpetuates feminine oppression in postcolonial Africa. It is this subplot of wife battery that introduces the indictment of doctors and their method of diagnosis and treatment.

By consensus, Chief Zebrudaya, Prince Jegede, and Gringory admit that this set of teeth belongs to an animal, but how did it come into the kitchen since Chief Zebrudaya never remembers killing a goat? Ovuleria's response settles and raises again the dust of this teeth-of-a-goat saga. She admits eating goat heads as a therapy for her undisclosed sickness. According to doctor's prescription, she is obliged to eat 12 goat heads every week or 48 goat heads a month, a treatment that Chief Zebrudaya and Prince Jegede find preposterous. Both friends query the ab/use of esoteric medical jargons, meant to heighten the fear of a patient and therefore induce his/her vulnerability or openness to exploitative and materialistic tendencies of Nigerian doctors who use "medula oblangatone for cold; pancrocacus ibesity for nail piercing of leg; magomago hypernexia for razor cutting of nail with blood". Although there are no diseases as such words in italics, Chief Zebrudaya, as a merchant of humor, uses these neologisms to comically buttress doctors' profiteering proclivity and professional abuse of medical ethics in Nigerian society. Like in Molièresque comedy, the aesthetic deployment of humor appears omnipresent all episodes of The New Masquerade.

Molière structures his theatre through the fabrics of humor, deploying satire and situational irony as means of foregrounding the social commitment of his comedy. His play presents a denouement that sets up situational irony by creating anticlimax of expectation. In L'Avare, Valère ends up marrying Elise while Cléante is joined with Mariane to Harpagon's chagrin. L'Ecole des femmes ends with Agnès choosing Horace over her tutor, mentor and suitor, Arnolphe who, despite his 11 commandments of a good wife (Acte 111 Scène 2), remains, like Harpagon and Tartuffe, a didactic object of satires. Laughter is triggered when Horace unsuspectingly gives a derogatory description of de la Souche before his interlocutor who happens to be de la Souche, but only known to him as Arnolphe (Acte 1, Scène 4). In the same vein, it is incongruous for Harpagon to suspect himself, alongside all members of his household, of stealing his own money. The French dramaturge intends to satirize Harpagon's mania for materialism; he prefers to stock up wealth than care for his children, Cléante and Elise. So, humoristic theories of incongruity, superiority and release are inherent in Molière's comedies, like in The New Masquerade, that coalesce verbal and non-verbal types. Antonio Reyes et al (2009) rightly state that humor is "a subjective and fuzzy entity that changes according to culture, societies, persons or mood" (p.312), yet humoristic theories could be applicable in all cultures because katagelasticism which Renner and Heydasch (2010) define as the joy of laughing at others is a universal phenomenon.

The New Masquerade deploys the dynamics of humor from performative to expressive aspects of joking. Chief Zebrudaya appropriates hilarious costumes to his adult servants who engage in domestic chores of sweeping, running errands, and washing plates, considered derogatory for adult Ibo Africans, but suitable for children who are always used as servants in middle/upper class homes. This scene of adult servants might not be humorous for Western audience because of Reyes et al (2009)'s socio-cultural relativity of humor. Unlike Ibo African society, French cultures, represented in Molière's comedy, reserve the works of domestique (servant) for the Third Estate, mostly the poor youth/adults. 
Although their work can be termed belittling in the context of African social pride, Gringory and Clarus can be described as gelotophiles and katagelasticists who "play active or agentic roles in this drama of laughing" (Renner and Heydasch, 2010, p.176) while Chief Zebrudaya and Prince Jegede (as representative of Middle Class) can be called katagelasticists and gelotophobes who laugh at others but do not enjoy being laughed at. In "The Visit of Mr Bewitch Bankrovitch", the Whiteman's name, satirically coined, amuses Chief Zebrudaya, Ovuleria and Apeno who desire to know if the Russian immigrant works in a bank. Mr. Bankrovitch's symptomatic reaction after eating kola nut with ose oji further creates an atmosphere of humor as he helplessly screams for water to prevent him from choking. Chief Zebrudaya's expressions of incongruity and opposite senses as triggers of humorous meanings consist in rewriting conventional proverbs, twisting of logics, transgressions of grammar codes and neologisms. He tells Mr. Bankrovitch that "charity begins abroad" instead of conventional "charity begins at home" as a means of contesting the appropriation of bad and evil things to African continent while questioning the Whiteman's repeated shouting of "goodness Lucifer" because "Lucifer is the DPO of devils" (that is District Police Officer). In "Stop the Wedding 1 \& 2", Chief Zebrudaya says that "to error is humanity, to forgiveness is harmattan" in his attempt to forgive his houseboy's and daughter's secret marriage. While Philo speaks Standard English, Gringory speaks poor Pidgin that generates humorous meanings. In Philo's rehearsals of wedding wows with him as specified by her pastor, he says "if God be my NEPA (Nigerian Electric Power Authority)" instead of "if God be my helper". He calls father in-law, "father in-lawyer". Fragrant abuse of the proverbial expression, individual creation of meaning and neologism are a type of protestation that culminates into the death of English grammar in The New Masquerade.

\section{Death of Grammar: Linguistic Appropriation in The New Masquerade}

Ogunpitan (2007) admits that Ken Saro Wiwa's Sozaboy celebrates the death of English grammar because the work adopts rather Nigerian Pidgin codes. Postcolonial writers' indigenization of European languages recalls what Ashcroft et al (2002) baptize as "textual strategies in postcolonial writing" or simply "the appropriation and reconstitution of the language of the centre, the process of capturing and remolding the language to new usages" (p.37). This linguistic phenomenon produces in Francophone African literature what Ayeleru (2002) calls frankongolisation in Sony Labou Tansi's writing and Ajah (2009) describes as fonfrancisation in Olympe Bhêly-Quenum's works. However, The New Masquerade produces a phenomenon that alternates between Standard English, Pidgin and Ibo language, a linguistic particularity that conveys and catalyses the dynamics of humor in this TV series. In classical French theatre, Molière was often censured and accused of language excesses such as "les enfants faits par l'oreille" in L'Ecole des femmes, lacking in classical aesthetics of "vraisemblance" and "bienséance" that defined the concept of "honnête homme", that is, conformism to the Ideal of French seventeenth century. Like the French classical humorist, Chief Zebrudaya has received verbal attacks from scholars who accuse him of murdering English or what Teilanyo (2008/9) describes as "the nonstandardness observed in the use of English idiomatic expressions, tropes, maxims, and African proverbs" (p.73) in Masquerade.

Ilagha's "Zebrudaism", defined as violence to English grammar in Nigeria, explains rather positively The New Masquerade's postcolonial linguistic evolution that distinguishes its language as a postcolonial oral text. Chief Zebrudaya as a character or James Iroha as his creator, had a choice of Standard English, but tended towards linguistic particularism to produce a Creole of Nigerian Pidgin, making the TV series a nationalistic play for local audiences. James Iroha is analogous to the prolific Creole dramatist Dev Virah Sawmy who has produced a remarkably successful series of plays, most often performed for popular audiences in Mauritius, but his fame is inevitably restricted to his Island home (Hawkins, 2008, p.13). The Masquerade and its creator also lacks in fame internationally because of its localized broadcasting, its linguistic appropriation and of what Teilanyo (2008/9) attributes to problems involved in comprehending and interpreting the contextual imports of metaphysical uses by incompetent users of English in Nigeria. In essence, Teilanyo and other critics subjectively describe Chief Zebrudaya's language as a product of illiteracy not of premeditated choice that aligns itself with the pleasure of the poor masses and the social space of Nigerian postcoloniality. The New Masquerade's misreading parallels the Western misinterpretation of Amos Tutuola's Palm-Wine Drinkard or Ken SaroWiwa's Sozaboy postcolonial texts, but Chief Zebrudaya's creative language aligns itself with Ahmadou Kourouma's linguistic realism in Allah n'est pas obligé where he uses his Malinké dialect as raw material for creating French words. Zebrudayan language employs "highly developed strategies of code-switching and vernacular transcription, which achieve the dual result of abrogating the Standard English and appropriating an english as a culturally significant discourse" (Ashcroft et al, 2002, p.45) and as a means of signifying difference (p.50). Though a mix of English, Pidgin and Ibo dialect, it partially constitutes Nemser's and Selinker's interlanguage which Ashcroft et al (2002) define as "the genuine and discrete linguistic system employed by learners of a second language" (p.66) which "n'est pas seulement 
composée de formes correctes et de règles propres au système et à la norme de la langue-cible, mais aussi de formes grammaticalement incorrectes et de règles non conformes à la langue-cible" (Mourra, 1999, p.82). The use of Zebrudayan creative language is represented in all episodes of The New Masquerade, though only three are emphasized in this work.

In "The Visit of Mr. Bewitch Bankrovitch", Chief Zebrudaya explains the African "customary mannerism" of offering of kola nut to Mr. Bankrovitch who refuses to say Ise during prayers before Kola nut is broken and served, thereby wondering "what are the difficurity hard in concurring Isee especially among the "chopperers" of kola nut. Chief Zebrudaya describes mannerism with customary or difficurity (difficulty) with hard, such a tautologous selection from a pool of synonyms is consciously a means of generating humor in the TV comedy. His neologism "chopperer" appears a derivative of Nigerian Pidgin, chop (to eat); the addition of er suffix to already a noun form of chop, chopper plays the same role of happy congratulation in "Stop the Wedding", to amuse local audiences. He goes further to create "choplated" and "chopped" as past tenses of chop, though Nigerian Pidgin rarely uses verbs in the past, instead don is added to historicize the experience, you don chop? (Have you eaten?). Against this background, Zebrudayan language oscillates between Pidgin, Standard English and Ibo as he uses compound words such as "ite pot" (ite means pot in Ibo dialect), tumbo liquor (locally made gin) and Chineke God (Chineke means God in Ibo). In challenging the arbitrariness of Standard English, he employs expressions such as "father in-lawyer" or "my greatest suprisation" in "Stop the Wedding", "a personal and bona fide property" in "The Teeth of a Goat" and "too muchly" in "The Visit of Mr. Bewitch Bankrovich". Zebrudayan neologisms are tactful transgressions of Standard English; tenses are abused; nouns are used as verbs and verse versa <disturbance me, to correction you, the put of semicolony, refusal his brother>, analogous and typical of Nigerian Pidgin and interlanguage which abuses grammatical rules. In the play's social space, Chief Zebrudaya speaks his hybridized language which nobody speaks but everybody understands including Mr. Bankrovitch, the Russian medical research fellow, thus fulfilling the primary function of language as a means of communication. The New Masquerade exemplifies the deconstruction of hegemonic Western representation and showcases how the colonizer's language serves the interest of the colonized in a postcolonial oral text which has been misjudged and misread by critics.

\section{Conclusion}

Chief Zebrudaya, major character of The New Masquerade, is distinguished as a merchant of humor whose art and artistry have attracted disapprovals from humanities scholars, especially in the area of language use. By the duty of his comedy and the dynamics of his creativity, it is possible to describe Chief Zebrudaya as an archetype of Molière who, as a dramaturge and actor, is known for his comic genre and polemic. Molière and Chief Zebrudaya, as a creator of comedy and character of comedy respectively, explored the potential of theatre as a means of correcting the ills of human society, thereby using unconventional and controversial approaches to achieve their nationalistic projects. While Molière's criticism results from his "transgression" of Classical rules of bienséance and vraisemblance in some of his works, Chief Zebrudaya is blamed for his "transgression" of Standard English grammar that permits him to produce a Creole formed from European language, Nigerian Pidgin and Ibo dialect; both comedians can be said to be pleasing the public audiences than the intellectuals of their time. As Moliere's characters such as Don Juan, harpagon, Tartuffe or tartufferie have entered into French lexicons from the world of text, Chief Zebrudaya depicts comedy in Nigerian social space as a copyrighted cultural character whose acceptance cuts across Nigerian tribes. Although Nigerian audience regrets the untimely "death" of The New Masquerade, it ruminates with this play that presented subtle satires and faceless farce of Nigerian politics and policies by inventing a postcolonial language that attempts to "write back" to the Centre.

\section{References}

Ajah, R. O. (2009). La Fin du Monde: Etude Postcoloniale du Chant du Lac d'Olympe Bhêly-Quenum. Agora: Journal of Foreign Language Studies, 3, 144-163

Ashcroft, B et al. (2002) The Empire Writes Back. (2nd Ed.). London \& New York: Routledge.

Ayeleru, B. (2002). La Langue de la Littérature Africaine Francophone: Entre une Identité et Un Hybride Linguistique. Ibadan Journal of European Studies, 3, 68-91.

Bailey, M. M. (1998). The Last Visitor's Note. (excerpts/reprint of: "Reflections on a Conversation with Efua Sutherland: an Artist with a Vision,") Glendora Review: African Quarterly on the Arts, 2 (3\&4), 14-18

Edem, G. (2000). Female Characterization in Francophone African Drama. In Sam Ade Ojo \& Olusola Oke (Eds.), Themes in African Literature in French. Ibadan: Spectrum Books Ltd, 263-301

Epistein, P. (2001). Marriage in Molière's Misanthrope. Animus, 6, 62-102.

Griffiths, G. (1999). African Literatures in English. London: Longman. 
Hall, G. (1977) Molière Satirist of Seventeenth-Century French Medicine: Fact and Fantasy. Proc.roy.soc.med, 70, 425-431.

Hawkins, P. (2008). Until When Shall We Remain Postolonial? Globalisation, Nationalism and Cultural Self-determination in the Literatures of the Indian Ocean. E-France: An Online Journal of French Studies, 2, 9-18

Hayes, J. \& Okome, O. (1997). Evolving Popular Media: Nigerian Video Films. In J. Hayes (Ed.), Nigerian Video Films. (pp.21-44). Jos: Nigerian Film Corporation.

Iroha, J. \& The Masquerades. The Visit of Mr. Bewitch Bankrovich. $C D$.

Iroha, J. \& The Masquerades. The Teeth of a Goat. $C D$.

Iroha, J. \& The Masquerades. Stop the Wedding 1 \& 2. $C D$.

Mason-Dean, M. E. (2009). Molière, Game Theory and Capitalization: An Economic Analysis. Explorations: An Undergraduate Research Journal, 7-22.

Mbamara, O. \& Nnorom, F. (2006). I will not Play a Role that Mainly Depicts Evil. (Interview with African Events. Com).

Moliere. (1992). L'Ecole des femmes (1662). Paris: Hachette.

Moliere. (1992). Tartuffe (1664). Paris: Hachette.

Moliere. (1992). L'Avare (1668). Paris: Hachette.

Moliere. (1992). Le Médecin malgré lui (1666). Paris: Hachette.

Mourra, J-M. (1999). Littératures francophones et théorie postcoloniale. Paris: Presses Universitaires de France.

Musa, R. A. (2006). The Drama and Theatre of Wole Soyinka. An Encyclopaedia of the Arts, 11 (3), 216-229.

Nelson, J. K. (1971). Fielding and Molière. PhD Thesis, Rice University.

Okome, U. (2007). Comic Dramaturgy and Societal Re-awakening in Yerima's The Lottery Ticket. In U. Atakpo and S. E. Inegbe (Eds.), Making Images, Re-making Life: Art and Life in Ahmed Yerima. (pp.161-175). Uyo: Modern Business Press.

Ogunpitan, S. A. (2007). Genotext and Intertext: The Grammatology of a Literary Idiolect. California Linguistic Notes, XXXII (2), 2-15.

Oyono-Mbia, G. (1977). Trois Prétendants...un mari. Yaoundé: Editions CLE.

Reyes, A. et al. (2009). Humor in the Blogsphere: First Clues for a Verbal Humor Taxonomy. Journal of Intelligent Systems, 18(4), 311334.

Renner, K-H \& Heydasch, T. (2010). Performing Humor: On the Relations between Self-Presentation Styles, Gelotophobia, Gelotophilia, and Katagelasticism. Psychological Text and Assessment Modeling. 52 (2), 171-190.

Skinner, C. A. (2011). The Misanthrope: Accepting the Notions of Molière into a Modern Society. MA Thesis, University of Nebraska, USA.

Teilanyo, D. (2008/9). Literary Usage in English as a Second Language in Nigeria: A Study of 'Icheoku' and 'Masquerade'. Africa Today, 55 (4), 73-121

Teilanyo, D. (2010). Paralinguistic and Non-Verbal Props in Second-Language Use: A Study of Icheoku and Masquerade in Nigeria. Language in India, 10, 52-65.

The University of Akron. (2005). Tartuffe by Molière, Study Guide, The University of Akron.

Zajc, M. (2009). Nigerian Video Film Cultures. Anthropological Notebooks, 15 (1), 65-85.

Zoberman, P. (2005). Domestic Economy in Molière's Comedy. Seventeenth-Century French Studies, 27, 103-115.

Zukaitis, K. (2009). Religious Metaphor in Molière's L'Ecole des femmes. Glossolalia, 1. 